2005

\title{
Objecting to Court Ordered Mediation
}

Jane C. Murphy

University of Baltimore School of Law, jmurphy@ubalt.edu

Follow this and additional works at: http://scholarworks.law.ubalt.edu/all_fac

Part of the Dispute Resolution and Arbitration Commons, and the Legal Ethics and Professional Responsibility Commons

\section{Recommended Citation}

Objecting to Court Ordered Mediation, 38 Md. B.J. 54 (September 2005)

This Article is brought to you for free and open access by the Faculty Scholarship at ScholarWorks@University of Baltimore School of Law. It has been accepted for inclusion in All Faculty Scholarship by an authorized administrator of ScholarWorks@University of Baltimore School of Law. For more information, please contact snolan@ubalt.edu. 


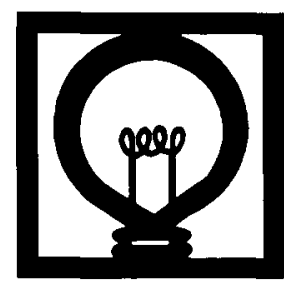

\section{$\begin{array}{llllllllllll}\text { P } & \text { IR } & A & G & \mathbf{T} & \text { I } & \text { C } & \text { E } & \text { T } & \text { I } & \text { P } & \text { S }\end{array}$}

\section{Objecting to Court Ordered Mediation}

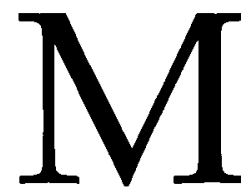

aryland judges have wide discretion to refer parties to mediate a variety of civil matters. Title 17 of the Maryland Rules, enacted in 1998, governs mediation of civil cases in the circuit courts. These rules are supplemented by Maryland Rule 9-205, which addresses mediation of child custody and visitation disputes. Although these rules define mediation and address mediator qualifications in some detail, they say very little about either a party's right to object to mediation or the court's authority to compel participation in mediation.

Given that the mediation rules are relatively new and mediation orders would generally be considered interlocutory, no appellate law on the scope of the court's authority to compel participation in mediation currently exists in Maryland. With this lack of clarity in the law, practitioners may have some question about their options when faced with an order to mediate.

In many cases, compliance with the order will be in the best interest of the client. But attorneys should always consider whether mediation is the most appropriate dispute resolution method for the client and the particular case. This practice tip will offer some guidance about when mediation might not be in your client's best interest, how to make an objection to a mediation order and what to expect from the court.

\section{Advising Against Mediation}

Mediation can be a very positive option for clients in that it may, among other benefits, reduce the delay and expense of litigation and improve relationships and communication between opposing parties. In fact, under Maryland's recently revised Rules of Professional Conduct that become effective July 1 , 2005 , attorneys may have an obligation to discuss mediation as an alternative to litigation with their clients. Comment 5 to Rule 2.1 provides: "[W] hen a matter is likely to involve litigation, it may be necessary under Rule 1.4 [Communication] to inform the client of forms of dispute resolution that might constitute reasonable alternatives to litigation."

Thus, even those attorneys who do not expect to mediate themselves should be familiar with both the practice and theory of mediation in order to competently advise their clients. This advice might include, from time to time, the suggestion that clients not elect to mediate their cases and, if ordered by the court to attend mediation, to file an objection. Some situations in which to consider filing an objection include:

1) There is an imbalance of power between the parties that would interfere with the mediation process

The existence of a power difference between parties to mediation is one of the most frequently discussed grounds for objecting to mediation. These power differentials may occur on a number of levels. They may relate to differences in emotional or physical power and may include a history of power and control of one party over another, as in abusive family relationships.

Power imbalances may also stem from differences in financial resources. A power imbalance, often connected to economic differences between the parties, may also result when one party is represented by an attorney and the other is not. Again, these differences may occur in the context of family relationships, but may also be present in employee/employer relationships, consumer/business relationships and other relationships common in the mediation setting. 
Power imbalances can interfere with the mediation process and pose risks of intimidation and coercion by the stronger party against the weaker party. The norms of mediation discourage the mediator from interfering with the substantive direction of the dialogue and negotiation. Moreover, mediation is private and informal with few of the procedural safeguards or opportunities for review that can work to "level the playing ground" in litigation.

All of these circumstances contribute to the risk that the domineering party will control the terms of the discussion and, ultimately, any agreement that results from mediation. The risks are especially high in family mediation involving abusive relationships where mediation may rarely, if ever, be advisable.

2) The opposing party has demonstrated bad faith or a regular pattern of noncompliance

Objections to mediation based upon bad faith often occur after the mediation has been ordered and one party refuses to participate in a meaningful way-failing to attend, attending but without authority to settle, etc. Some states' legislatures and courts have adopted rules requiring good faith participation in court-connected mediation and imposing sanctions for violations. See, e.g. Cal. Fam. Code $\S$ 8616.5(e)(3), (f), (h)(2)(C) (2003); D.C. Code Ann. § 5-1108(3) (2005); W. Va. Code §19-23-6(18)(2005).

Although Maryland has not yet enacted similar rules, counsel should consider filing an objection to participating in mediation if an opposing party or counsel has demonstrated bad faith prior to or during mediation, for example, regularly failing to respond to discovery requests and/or failing to appear at scheduling conferences or at other times, or otherwise demonstrating a lack of commitment to meaningfully participating in mediation. If any of these circumstance have been present, having your client attend mediation would likely result in unnecessary expense and delay the resolution of the case.

\section{3) Case raises new and complex} issues of law on contested issues

Occasionally an individual or organizational client will pursue a dispute with a primary or secondary goal of establishing new law. While not common, we have all represented clients for whom "the principle" becomes more important than resolving the dispute. Client motivation may be financial, political or altruistic. In some instances, the client's motive may be more irrational, and pursing litigation over mediation may not be in that client's best interest.

Those clients should be strongly counseled to pursue settlement through mediation or another alternative dispute resolution process. But, where the client has a reasonable chance of success on the merits and has both the resources (pro bono or fees), and a strong commitment to an issue, litigation may be the most appropriate course to take as it is the only method of resolving a dispute that will create precedent to guide future disputes involving the same issue (s).

4) Mediation is unlikely to resolve the matter and would delay resolution or add substantial expense.

Another situation in which media- tion may not be advisable is the "high conflict" case. These are cases, most common where the parties have a long-term relationship such as family or employment relationships, where there is a history of conflict and repeated litigation between the parties. Some may argue that these are cases where mediation may be most appropriate.

Those that subscribe to the "transformative" approach to mediation

would, in fact, see the mediation process itself as a means of changing the pattern of conflict between the parties. You should be familiar with this and other approaches to mediation and consider its benefits for your client.

Even after considering the potential benefits of this approach, you may still believe, given the particular parties and circumstances of your case, that there is no possibility of voluntary agreement or compromise and that compliance with a mediation order would only add expense and delay for your client. The grounds for this objection may be similar to the bad faith cases, but stem from different circumstances.

These are the cases where the differences are so longstanding and fundamental that meaningful dialogue about settlement between these particular parties is, in your judgment, not possible. The issue may be over custody of a child or an alleged civil rights violation or other issue that is not susceptible to compromise for your client.

5) One or both parties has, because of physical or mental disability, diminished capacity that interferes with the ability to meaningfully participate in mediation

One of the benefits of mediation is 
that it provides an opportunity for the parties to engage in self-determination and reach agreements designed by the parties. Ideally, the parties, not the mediator or lawyers, control the process and the result. The success of mediation, therefore, depends, to a far greater extent than litigation, upon the capacity of the parties for this kind of work.

If your client or the opposing party's ability to engage in this process is diminished substantially by substance abuse, mental illness or other disability, mediation may not be productive and advisable. While such conditions should not automatically rule out mediation, counsel should consider the limitations of their clients before participating in mediation.

\section{Making Objections to the Court to Mediation Orders}

The only ground delineated in the Maryland Rules for polential exemption from a mediation order is the domestic violence exception in Maryland Rule 9-205, which governs mediation of child access cases. Rule 9-205(B)(2) provides that "(i)f a party or a child represents to the court in good faith that there is a genuine issue of physical or sexual abuse of the party or the child, and that, as a result, mediation would be inappropriate, the court shall not order mediation."

While the rules seems to leave some discretion to the court to determine whether mediating a case involving family violence is "appropriate," attorneys should always counsel clients about the risks of mediation in cases in which a client or the child have experienced abuse. And if the court orders mediation in such a case, counsel should certainly consult with their clients about filing an objection.

Courts are just beginning to develop formal procedures for screening out domestic violence cases from mediation programs and it is often necessary for counsel to identify the case as one that fits within the Rule 9-205 exemption. As a result, mediation orders are, in my experience, almost always set aside in response to an objection based on domestic violence.

Title 17, governing orders to mediate in non-family circuit court civil cases, does not delineate the grounds for objecting to orders to mediate. The rules do, however, recognize that objections may be made to mediation orders or referrals and seem to provide wide latitude to the court to grant such objections. Rule 17-103 (2) lays out the procedure for making an objection and provides, in part, that " the court shall give the parties a reasonable opportunity (A) to object to the referral [to mediation];" [and] "(B) to offer an alternative proposal."

The rule further provides in 17103(3) that " $[t]$ he court shall give fair consideration to an objection to a referral" and "may not require an objecting party to participate in an alternative dispute resolution proceeding other than a non-fee-forservice settlement conference." Rule 17-102(h) makes clear that the nonfee-for-service settlement conference is the procedure, routine in many courts, where parties are encouraged to settle by a court officer or volunteer attorney, a process quite different from mediation. Thus, it appears, at least in non-child access cases, that Title 17 does not give the court the power to compel mediation.

Despite the likelihood that the court will not impose formal sanctions on clients or attorneys who fail to participate in mediation, failure to participate in mediation may adversely affect the outcome of the case unless the parties have been excused from the court order. Counsel should, therefore, comply with the procedures set forth in the Maryland Rule 17-103 and file a timely objection carefully laying out the reasons why mediation may not be appropriate in your case.

Unless the objection can be grounded in an allegation of domestic violence in a child access case, counsel should frame their objections in terms of "good cause" or "undue hardship," common language for exempting cases from mediation in many state statutes. While these grounds are not explicitly set forth in Maryland's mediation rules, they provide reasonable "catch all" language to describe the circumstances, set forth above, in which your client may decide against mediation.

Finally, because mediation is a relatively new and expanding area of law, rule changes and case law on this topic are likely to develop in the future. As always, practitioners should stay abreast of changes in this area of the law and check Title 17 and related rules whenever they believe it is appropriate to object to a mediation order.

\section{By Jane C. Murphy}

Ms. Murphy is on the faculty of the University of Baltimore School of Law. Ms. Murphy may be reached at jmurphy@ubalt.edu. 